\title{
Dust Explosions - Hazards, Prevention, and Protection
}

\author{
Martin Glor
}

\begin{abstract}
An overview of the occurrence and characteristics of dust explosions is given. The prerequisites for the formation of a dust explosion are discussed. In particular the importance of the knowledge of the safety characteristic data to assess the ignition hazards due to the different ignition sources occurring in practice is outlined and explained. The measures of explosion prevention and explosion protection are summarized and their advantages, disadvantages, limits and requirements are listed.
\end{abstract}

Keywords: Dust explosions · Explosion prevention · Explosion protection · Ignition hazard $\cdot$ Ignition sources

\section{Introduction}

In many branches of industry the awareness of the hazards associated with dust explosions is still rather poor, though the effects and damages can be even more serious than in the case of gas or vapour cloud explosions. Dust explosions have not been invented in modern times, they started to occur as soon as flammable solids were broken up or ground in industrial processes such as milling operations. Reports of dust explosions date back to the 18th century when grains began to be ground in windmills. With growing industrialization and

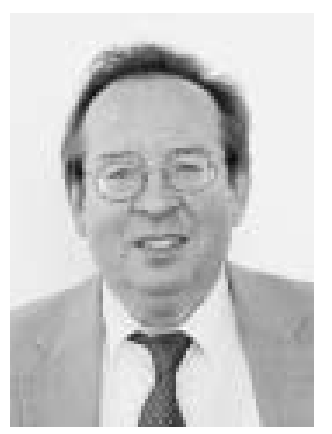

${ }^{*}$ Correspondence: Dr. M. Glor Member of Executive Committee Swiss Institute of Safety \& Security WKL - 32.3.01

$\mathrm{CH}-4002$ Basel

Tel.: +41616962211

Fax: +41616967072

E-Mail: martin.glor@swissi.ch larger scale production more and more products were recognized to be potentially hazardous with respect to dust explosions. Nowadays it is well known that any product that burns in the solid state may undergo a dust explosion if it is finely dispersed in air in the form of a dust cloud. Even products such as aluminium, which hardly burn in the solid state because the surfaces are quickly oxidized when exposed to air, may form very dangerous explosive dust clouds.

Many products are purchased in powder form or they undergo processes and operations in which the formation of fines itself is part of the designed process or at least cannot be avoided. This applies particularly to products of the chemical and pharmaceutical industry, where the following processes and operations are very common: milling, mixing, shredding, spray or fluid bed drying, powder coating, pneumatic transfer, dust ventilation, dust separation, filling, emptying, etc. Whereas in most of these processes the formation of a dust cloud is restricted to the interior of an apparatus, the probability of the formation of a dust explosion in the production area by whirling up deposited powder should not be underestimated. This particularly applies to branches of industry where - from the point of view of industrial hygiene - rather uncritical products are handled and processed. The severe dust explosion which occurred 1979 in the Rolandmühle in Bremen with 14 fatalities and 17 seriously injured demonstrates this hazard [1]. Though statistical data have always to be interpreted with caution, Fig. 1 and 2 may give some information about the relative frequency of dust explosions with respect to different products and with respect to different operations and processes.

\section{Hazards}

The hazards of dust explosions are similar or - as far as heat radiation is concerned - even more serious than those of gas or vapour cloud explosions. The characteristics and the course of dust explosions are nowadays well understood and investigated. They are reported in numerous publications, articles and textbooks [1-3]. Dust explosions do not only generate blast waves, projectiles and heat radiation, which are dangerous for the personnel, the equipment and installations, they are often also the origin of subsequent fires, which may destroy whole production plants. For all of these reasons they have to be taken very seriously.

Dust explosions may occur if flammable solid material is subdivided into fine particles dispersed in air. Particles with a diameter of more than $0.5 \mathrm{~mm}$ no longer form an explosive dust cloud. Fine particles may however also be formed during the handling and processing of granules due to abrasion. The finer the particles are, the more violent will be the explosion and the more sensitive will be the dust cloud with regard to ignition sources. For a worst case assessment, the fraction below a mesh size of $63 \mu \mathrm{m}$ is usually chosen. Under atmospheric conditions dust explosions normally show the following characteristics [1-3]: 


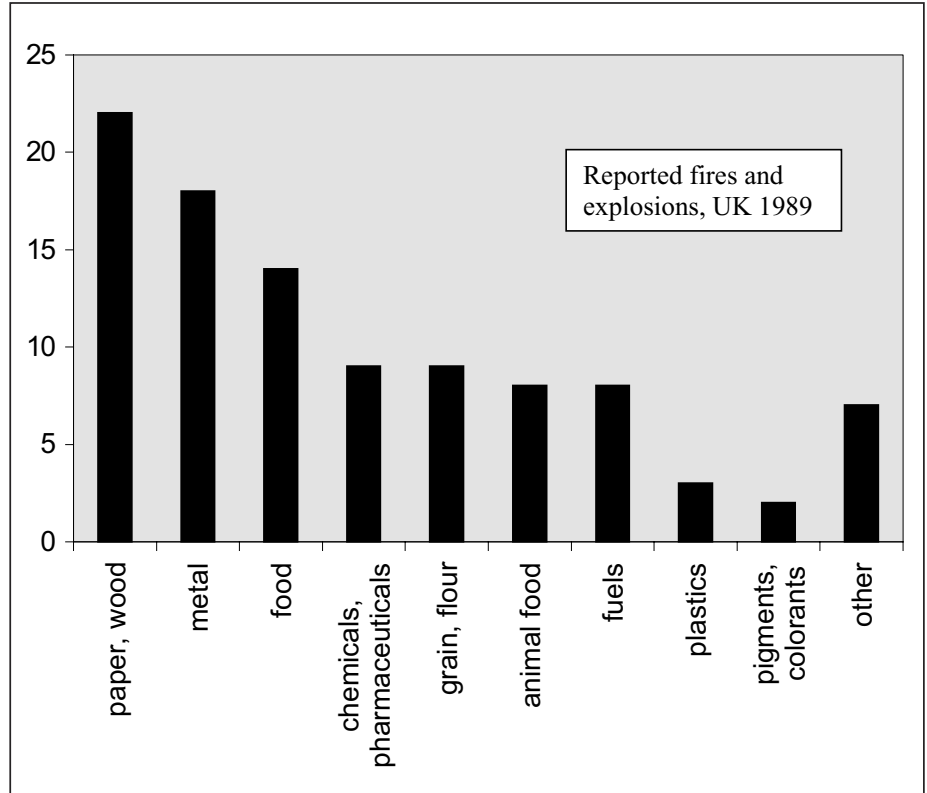

Fig. 1. Statistics of fires and explosions for different products

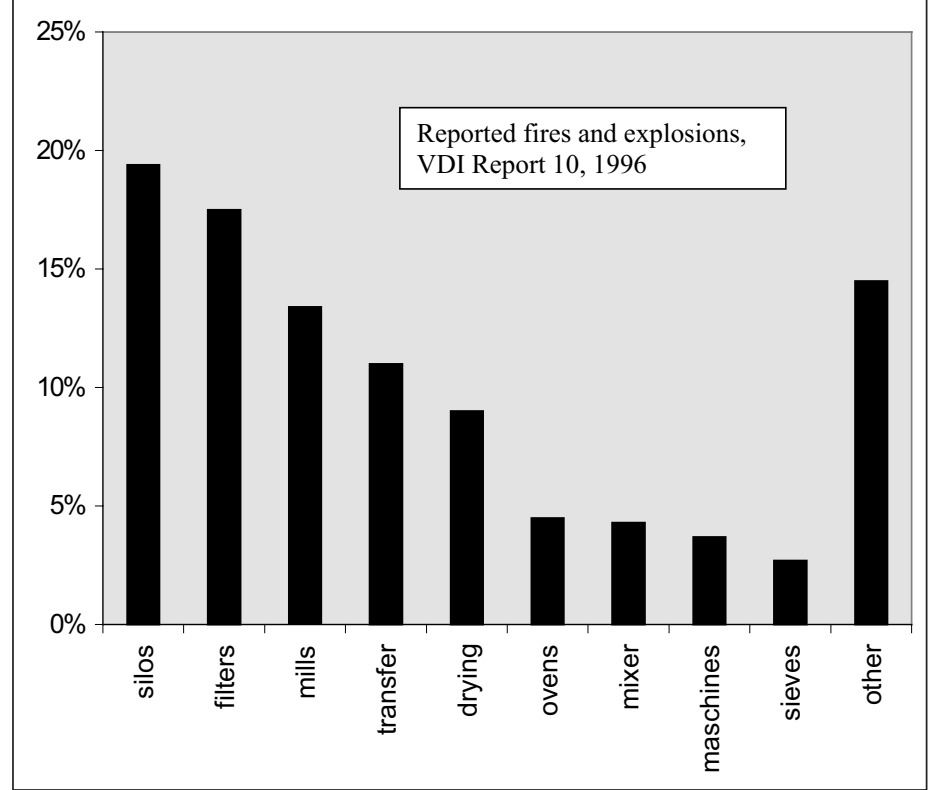

Fig. 2. Statistics of fires and explosions for different processes and apparatus
- Explosion range: from $15 \mathrm{~g} / \mathrm{m}^{3}$ to several $\mathrm{kg} / \mathrm{m}^{3}$

- Maximum explosion overpressure: 9 bar for organic material and up to 13 bar for metal powder

- Maximum rate of pressure rise in a $1 \mathrm{~m}^{3}$ vessel: 100 to $300 \mathrm{bar} / \mathrm{s}$ for organic material and up to approx. $1000 \mathrm{bar} / \mathrm{s}$ for metal powder.

A simple calculation based on these characteristics shows that already a thin layer of e.g. $0.3 \mathrm{~mm}$ of product deposited on the floor and the surfaces of equipment and installations in a production building is sufficient to form a dust cloud with a concentration above the lower explosion limit, when whirled up by a blast wave.

As in the case of a fire, the prerequisites for an explosion are described by the wellknown fire triangle, which tells us that a dust cloud alone is not yet dangerous as long as it does not become ignited. In addition to an explosive concentration of the fuel dispersed in air, an ignition source of sufficient energy must be present at the same time and space to form an explosion. The dust explosibility of powders is usually tested with very strong ignition sources $\left(10 \mathrm{~kJ}\right.$ in a $1 \mathrm{~m}^{3}$ vessel and $2 \mathrm{~kJ}$ in a 20 litre sphere). This safety characteristic tells us whether an explosive dust cloud can be formed or not. For a long period of time the ignition sensitivity of powders in the form of dust clouds has been underestimated. Therefore, the guidance given in old guidelines and codes of practice has been rather poor in the case of powders. Numerous investigations have been performed during the last 10 to 30 years demonstrating that many powders show rather high ignition sensitivities. With respect to ignition by low energy ignition sources such as static electricity or mechanical sparks, the ignition sensitivity of a dust cloud is of particular interest. It is characterized by the so-called minimum ignition energy (MIE) and minimum ignition temperature (MIT). Both the MIE and MIT are measured according to standard procedures (spark discharges produced in a specially designed circuit and apparatus and hot surface exposed to the dust cloud respectively) [1-3]. For a given material the ignition energy is lowest for very fine powder, homogeneously dispersed in a nearly quiescent dust cloud.

If the MIE of a product lies below $10 \mathrm{~mJ}$, the corresponding dust cloud may already be ignited by low energy electrostatic discharges. Experience shows that it is often very difficult to exclude reliably such ignition sources in practice. As a consequence powders with a MIE of less than $10 \mathrm{~mJ}$ should not be handled or processed in large amounts without further measures of explosion prevention or explosion protection. In addition it must be kept in mind that the MIE of powders is strongly affected by flammable gases or vapours. As soon as flammable gases or vapours are also present, so-called hybrid mixtures are formed and the MIE may drop from above $100 \mathrm{~mJ}$ to below $10 \mathrm{~mJ}$ or even into the range of the MIE of pure gases or vapours (typically 0.2 to $0.4 \mathrm{~mJ}$ for hydrocarbons) [1]. This occurs even if the concentration of the flammable gas or vapour is far below its own lower explosion limit.

In addition to static electricity and mechanical sparks many different ignition sources may be present in practice. A comprehensive list is given in [4]. The knowledge of the safety characteristics of pow- ders is most important to assess the ignition hazard during handling and processing. Table 1 shows an overview of the safety characteristics important for an assessment of the ignition hazards of dust clouds.

\section{Prevention and Protection}

The measures against dust explosions are divided into two categories:

Preventive measures. These measures prevent the occurrence of an explosion. They are subdivided into:

- Prevention of an explosive atmosphere (either by exclusion of flammable concentrations or by reduction of the oxygen)

Avoidance of effective ignition sources Protective measures: These measures mitigate the effects of an explosion so as to ensure the safety of workers and an acceptable level of damage of the equipment. The methods of explosion protection are:

- Explosion resistant construction for the maximum possible explosion pressure

- Explosion venting

- Explosion suppression

The measures of explosion protection must always be combined with methods to exclude the propagation of an explosion into other equipment or into the open (explosion isolation). Furthermore these methods require a certain mechanical strength of the equipment, which should at least correspond to the maximum reduced pressure of the still occurring explosion.

Though, as a general rule, the preventive measures - particularly the prevention 
Table 1. Overview of the safety characteristics important for an assessment of the ignition hazards of dust clouds

\begin{tabular}{|c|c|c|c|c|c|c|}
\hline \multirow[b]{2}{*}{$\begin{array}{l}\text { Type of } \\
\text { ignition } \\
\text { source }\end{array}$} & \multicolumn{6}{|c|}{ Safety characteristics } \\
\hline & $\begin{array}{l}\text { Minimum } \\
\text { ignition } \\
\text { energy }\end{array}$ & $\begin{array}{l}\text { Minimum } \\
\text { ignition } \\
\text { temperature }\end{array}$ & $\begin{array}{l}\text { Resistivity } \\
\text { of bulked } \\
\text { powder }\end{array}$ & $\begin{array}{l}\text { Burning } \\
\text { number }\end{array}$ & $\begin{array}{l}\text { Self } \\
\text { ignition } \\
\text { temperature }\end{array}$ & $\begin{array}{l}\text { Smoldering } \\
\text { temperature }\end{array}$ \\
\hline $\begin{array}{l}\text { Electrical } \\
\text { sparks }\end{array}$ & + & & + & & & \\
\hline $\begin{array}{l}\text { Static } \\
\text { electricity }\end{array}$ & + & & + & & & \\
\hline $\begin{array}{l}\text { Hot } \\
\text { surfaces }\end{array}$ & & + & & & + & + \\
\hline $\begin{array}{l}\text { Mechanical } \\
\text { sparks }\end{array}$ & + & + & & & & \\
\hline $\begin{array}{l}\text { Smoldering } \\
\text { product }\end{array}$ & & & & + & & + \\
\hline
\end{tabular}

Table 2. Summary of the advantages and disadvantages of the different safety measures as well as of the required safety characteristics important for a safe and reliable design

\begin{tabular}{|c|c|c|c|c|}
\hline & Advantages & Disadvantages & $\begin{array}{l}\text { Special } \\
\text { requirements }\end{array}$ & $\begin{array}{l}\text { Safety } \\
\text { characteristics } \\
\text { required }\end{array}$ \\
\hline $\begin{array}{l}\text { Exclusion of } \\
\text { ignition } \\
\text { sources }\end{array}$ & $\begin{array}{l}\text { No explosion } \\
\text { No emission } \\
\text { of product }\end{array}$ & $\begin{array}{l}\text { Reliability } \\
\text { questionable in } \\
\text { case of sensitive } \\
\text { product }\end{array}$ & $\begin{array}{l}\text { Serious risk } \\
\text { analysis required }\end{array}$ & See Table 1 \\
\hline $\begin{array}{l}\text { Exclusion of } \\
\text { explosive } \\
\text { concentration }\end{array}$ & $\begin{array}{l}\text { No explosion } \\
\text { No emission } \\
\text { of product }\end{array}$ & $\begin{array}{l}\text { Restrictions on } \\
\text { the process } \\
\text { design }\end{array}$ & $\begin{array}{l}\text { No dispersion of } \\
\text { deposited dust } \\
\text { No settling of } \\
\text { dispersed dust }\end{array}$ & $\begin{array}{l}\text { Lower explosion } \\
\text { limit } \\
\text { Upper explosion } \\
\text { limit }\end{array}$ \\
\hline $\begin{array}{l}\text { Reduction of } \\
\text { oxygen }\end{array}$ & $\begin{array}{l}\text { No explosion } \\
\text { No emission } \\
\text { of product }\end{array}$ & $\begin{array}{l}\text { Hazard of } \\
\text { asphyxiation }\end{array}$ & $\begin{array}{l}\text { Leak proof } \\
\text { equipment }\end{array}$ & $\begin{array}{l}\text { Limiting oxygen } \\
\text { concentration }\end{array}$ \\
\hline $\begin{array}{l}\text { Explosion } \\
\text { resistant } \\
\text { construction }\end{array}$ & $\begin{array}{l}\text { No emission } \\
\text { of product }\end{array}$ & $\begin{array}{l}\text { Explosion } \\
\text { occurs } \\
\text { Massive and heavy } \\
\text { construction } \\
\text { required }\end{array}$ & $\begin{array}{l}\text { High mechanical } \\
\text { strength of } \\
\text { equipment } \\
\text { Explosion } \\
\text { isolation }\end{array}$ & $\begin{array}{l}\text { Maximum } \\
\text { explosion } \\
\text { pressure } \\
\text { See also Table } 1\end{array}$ \\
\hline $\begin{array}{l}\text { Explosion } \\
\text { venting }\end{array}$ & $\begin{array}{l}\text { Technically } \\
\text { simple }\end{array}$ & $\begin{array}{l}\text { Explosion } \\
\text { occurs } \\
\text { Emission of } \\
\text { product } \\
\text { Installation } \\
\text { location } \\
\text { restricted }\end{array}$ & $\begin{array}{l}\text { Mechanical } \\
\text { strength of } \\
\text { equipment } \\
\text { Explosion } \\
\text { isolation }\end{array}$ & $\begin{array}{l}\text { Maximum } \\
\text { explosion } \\
\text { pressure } \\
\text { K-value } \\
\text { See also Table } 1\end{array}$ \\
\hline $\begin{array}{l}\text { Explosion } \\
\text { suppression }\end{array}$ & $\begin{array}{l}\text { No emission } \\
\text { of product }\end{array}$ & $\begin{array}{l}\text { Explosion } \\
\text { occurs } \\
\text { Technically } \\
\text { elaborate }\end{array}$ & $\begin{array}{l}\text { Mechanical } \\
\text { strength of } \\
\text { equipment } \\
\text { Explosion } \\
\text { isolation }\end{array}$ & $\begin{array}{l}\text { Maximum } \\
\text { explosion } \\
\text { pressure } \\
\text { K-value } \\
\text { See also Table } 1\end{array}$ \\
\hline
\end{tabular}

of an explosive atmosphere - should be applied as first priority, the final decision has to be taken as the case arises. As a very general rule 'prevention of an explosive atmosphere' is very frequently applied in the case of flammable gases or vapours, whereas measures of explosion protection are rather common in the case of dusts. Table 2 summarizes the advantages and disadvantages of the different methods as well as the required safety characteristics important for a safe and reliable design.

When taking decisions concerning the choice of preventive or protective measures many influencing parameters must be taken into consideration. This decision as well as the design of the safety measures requires expert knowledge. To ensure the safety of protective equipment and systems as well as of work equipment for use in places where explosive dust atmospheres may occur, these should comply with the corresponding national and international guidelines and directives [5-8].

Received: October 3, 2003

[1] W. Bartknecht, 'Explosionsschutz Grundlagen und Anwendung', Springer Verlag, 1993.

[2] M. Glor, 'Electrostatic Hazards in Powder Handling', Research Studies Press, Letchworth, Hertfordshire, England, 1988.

[3] R.K. Eckhoff, 'Dust Explosions in the Process Industries', Butterworth-Heinemann, Oxford, 1991.

[4] European Standard EN 1127-1, 'Explosive Atmospheres - Explosion prevention and Protection, Basic Concepts and Methodology', European Committee for Standardisation, Central Secretariat, Brussels, 1997.

[5] VDI-Richtlinie 2263, 'Staubbrände und Staubexplosionen, Gefahren - Beurteilung - Schutzmassnahmen', VDI Kommission Reinhaltung der Luft, Beuth Verlag, Berlin und Köln, 1992.

[6] Directive 94/9/EC of the European Parliament and of the Council of 23 March 1994 on the approximation of the laws of the Member States concerning equipment and protective systems intended for use in potentially explosive atmospheres.

[7] Directive 1999/92/EC of the European Parliament and of the Council of 16 December 1999 on minimum requirements for improving the safety and health protection of workers potentially at risk from explosive atmospheres (15th individual Directive within the meaning of Article 16(1) of Directive 89/391/EEC). Also known as ATEX 137.

[8] SUVA PRO, 'Ex-Zonen, Grundsätze des Explosionsschutzes mit Beispielsammlung', Publikation Nr. 2153.d, Suva Bereich Chemie, Luzern, 1997 (Ausgabe 2003 in Vorbereitung). 